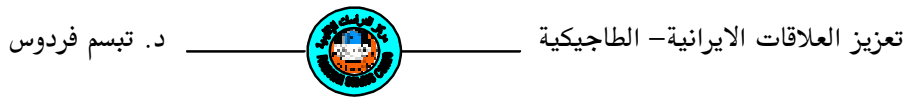

\title{
Deepening Iran-Tajik relations
}

\author{
QD. Tabassum Fivdaus \\ Ossistant professor (International Relations) \\ Qlniversily of Tashmir. India
}

\begin{abstract}
The paper treats with Iran's concentration mostly on Tajikistan and that Iran tried to establish new relationship based on cultural and linguistic affinity. Also, Iran expanded its economic clout in Tajikistan through investments in industry and energy sectors especially cement and hydropower projects beside, other various fields like mining and minerals, and trade ...etc. Flourishing economic ties with Dushanbe look to expand Tehran's political and strategic position in Tajikistan and the Central Asian region while it faces increasing international pressure over its nuclear program.
\end{abstract}

Tajikistan, once the underbelly of the erstwhile Soviet Union, is the only state from among the five Central Asian State of cisCaspian whose people are descend from the Irano-Aryan stock. Some historians are tempted to call them the descendents of the Indo-Aryan family. The word Tajik, occurring, often in Iranian history and literature. is the root from which Tajikistan has been formed. On the face of it, one may call Tajiks a specific ethnic group existing along the basin of Amu Darya or the Oxus.

Tajik language is the sister language of Farsi with excessive influence of Khurasani dialect. The region lying between the Amu and Syr Darya has generally been known to Iranian historians as 


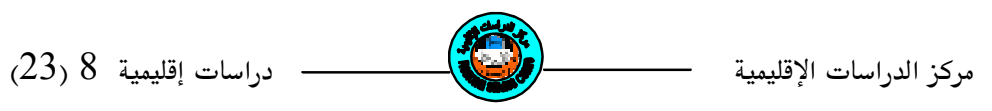

Turan. Its origin is traceable to Tur, one of the three sons of Feridun, the mythological Emperor of Iranzamin, who was allocated the region to rule on. He gave it the name of Turan ${ }^{(1)}$. Ferdowsi speaks of a long line of Turanian monarchs of whom Afrasiyab was the outstanding one. This great epic records many wars and fights between the Turanians and Iranians in the hoary past.

Over the period of time, Turan got parceled into regions, some were annexed and integrated into the eastern part of Iran called Khurasan, some formed the present northern areas of Afghanistan and some remained bracketed with Turkistan, the later name of Central Asian region with predominantly Turkic ethno-linguistic population ${ }^{(2)}$.

After the implosion of Soviet Union and declaration of independence by the Central Asian Republics in 1991, Tajikistan was faced with a civil war in which Pan-Islamists wanted to grab political power from the ruling communists now turned democrats. There was heavy loss of life on either side and finally in 1996, truce was signed through the intervention of Iran.

While Turkey tried to fill the vacuum in Central Asia by playing the Turkic ethnic and linguistic card, Saudi Arabia and Pakistan came with a big pro-Islamist agenda. But Iran concentrated mostly on Tajikistan and tried to establish new relationship based on cultural and linguistic affinity. This did work to some extent but Tajik policy planner did not allow Iran to make inroads beyond certain limits. However, in regional and international strategies, Iran continued to count on Tajikistan as a friendly country not jeopardizing the interests of Iran in the region. There developed understanding on some basic approaches to regional problems. Furthermore, Iran did not hesitate to use the good offices of Tajiks in her dealings with the Russian Federation. Incidentally, Iran-Tajikistan relations are purely secular 


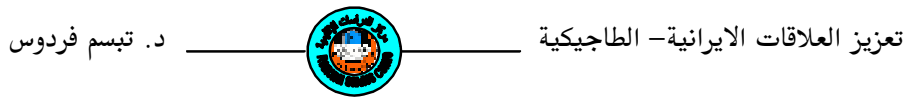

and non-sectarian, something remarkable to the understanding of each country. Iran did make considerable financial assistance to Tajikistan to help her come over the financial crunch that visited the country as a sequel to the civil war that ranged for nearly seven years. 1991-1996, and consumed about a hundred thousand youth.

Coming to current situation in the region and Tajik-Iranian relations, we know that Iran has steadily expanded its economic position in Tajikistan since the start of 2011. In February, a private Iranian company signed an agreement with the Tajik Ministry of Energy and Industry (MEI), pledging to build a large cement plant in Tajikistan's southern Khatlon province. When completed, the coal-driven plant is expected to produce two million metric tons of cement annually, using local limestone reserves. The company will also build a coal power plant to supply energy to the cement producing facility. According to the MEI, Iranian investment in the project will total $\$ 500$ million $^{(3)}$.

Iran's hitherto largest investment project in the country aims to help Tajikistan meet its steadily growing demand for cement. Boosted by large-scale energy and infrastructure projects, the demand is presently estimated at 1 million to 1.5 million tons per year and continues to increase. With domestic production standing at only 290,000 tons in 2010, Dushanbe has heavily relied on cement imports from Pakistan and Iran to meet its needs ${ }^{(4)}$. The Iranian-built plant is expected to provide Tajikistan with surplus cement output that can be used in new infrastructure projects or exported.

Tehran's embassy in Dushanbe also announced in February that Iran will continue investing in the Tajik energy sector.

Iran has already invested about $\$ 180$ million in the construction of the Sangtuda-2 hydropower plant (HPP) on the Vakhsh River in central Tajikistan. The final cost of the plant will increase markedly 


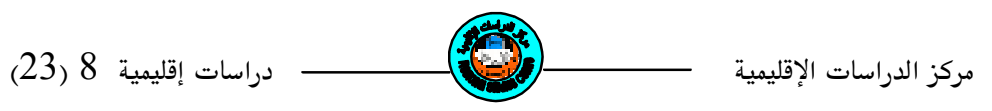

because, following the Tashkent-imposed ban on the transportation of materials for Tajik energy projects through the Uzbek railway, Tehran has to deliver critical supplies for the plant by air $^{(5)}$. The Sangtuda-2 HPP which is expected to begin operating this year will produce 220 megawatts of electricity annually, helping Dushanbe tackle its energy deficits.

The plant appears to be the first among several hydropower projects that Tehran intends to pursue in Tajikistan. After commissioning the facility, Iran will build the 170-megawatt Ayni HPP on the Zarafshon River in northern Tajikistan. Moreover, according to the Iranian embassy in Dushanbe, Tehran is currently reviewing the Tajik government's proposal to build two larger hydropower plants on the Obi Khingob River in Tajikistan's Rasht Valley. If completed, these plants will each produce an estimated 350 megawatts of electricity annually ${ }^{(6)}$.

While it remains unclear at the moment whether Tehran will have the resources and will be willing to build the three additional power plants in Tajikistan, these projects might help Iran become a major player in the country that has been its principal ally in Central Asia, Iran is among Tajikistan's major economic partners. Trade between the two countries stood at $\$ 400$ million in 2010 , up from $\$ 250$ million in the previous year. According to the Tajik investment committee, Tehran was the largest investor in the Tajik economy in 2010 , contributing $\$ 65.5$ million in foreign direct investment $(\mathrm{FDI})^{(7)}$.

In addition to increasing Iran's economic clout in Tajikistan, the energy projects will give Tehran additional political leverage in the country. Dushanbe has long viewed hydropower projects as the backbone for the country's development. The Tajik government views Tehran's intention to build the power plants on the Zarafshon and Obi Khingob rivers with particular appreciation because 


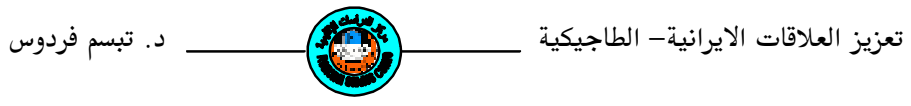

Uzbekistan's opposition to the plant had previously forced Chinese and Russian companies to abandon these projects ${ }^{(8)}$.

During his visit to Iran in March, Tajik President Emomali Rahmon also invited Iranian businesses to set up joint ventures with Tajik companies in the country's free economic zones. According to the Tajik president, the two countries are discussing the creation of such ventures in Tajikistan that will process fruit and vegetables, and produce energy saving light bulbs, solar panels and power transformers ${ }^{(9)}$.

Iran has also steadily increased its cooperation with Tajikistan's state geological agency, Geologiyai Tojik, which is responsible for the exploration and mining of minerals in the country. Iranian experts have been actively engaged in the exploration of gas and limestone reserves in Tajikistan. This cooperation has fueled speculation in the Russian media that Tehran sought to map out Tajikistan's uranium deposits as part of its global search for uranium for the country's allegedly peaceful nuclear program ${ }^{(10)}$.

There is little reliable data about economically viable uranium reserves in Tajikistan, partly because this information has been classified since the Soviet period. President Rahmon claimed in 2008 that Tajikistan was home to 14 percent of the world's uranium reserves. Subsequently, amendments were introduced to the national legislation, allowing foreign companies to mine uranium in Tajikistan $^{(11)}$.

It is currently impossible to verify the validity of claims by the Russian media about Tehran's interest in Tajik uranium. Flourishing economic ties with Dushanbe look certain to expand Iran's political and strategic position in Tajikistan and the Central Asian region at a time when Tehran faces increasing international pressure over its nuclear program ${ }^{(12)}$. 


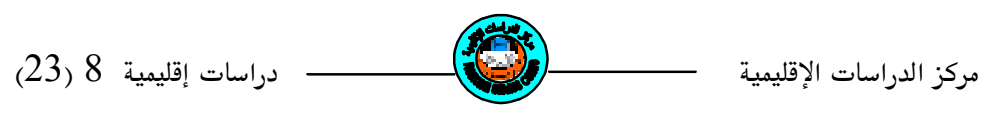

$$
\begin{aligned}
& \text { تعزيز العلاقات الإيرانية-الطاجيكية }
\end{aligned}
$$

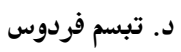

$$
\begin{aligned}
& \text { استاذ مساعد - قسم العلاقات الدولية - جامعة كشمير- الهند }
\end{aligned}
$$

يتناول هذا البحث اهتمام ايران الكبير بطاجيكستان ورغبتهـا الجامحسـة في إقامسة علاقـات جديـدة

معها قائمة على أواصر الثقافة واللغة. ويتناول البحث محاولات ايران توسيع نطاق نفوذهـا الاقتصـادي

في طاجيكستان من خلال الاسـتثمار في قطاعـات الصسناعة والطاقـة وعلى الأخسص في مشـاريع الاسمنـت

والطاقة الكهرومائية فضلاً عن المجالات المتعددة الأخرى كالتعدين والمعادن والتجارة... الخ ـ إن تعزيـز

العلاقات الاقتصادية لطهران مع دوشمبي كما يتضح من البحـث سـيعمل على تقويسة وضعها السياسي

والاستراتيجي في طاجيكستان ومنطقة آسيا الوسطى في الوقت الذي تواجسه فيـه ضـوطاً دوليـة متزايـدة

$$
\text { وخاصة ما يتعلق ببرنامجها النووي. }
$$

\section{Foot notes}

(1) Shahnameh of Ferdowsi

(2) See V. Barthold's Four Studies on Central Asia. P.37

(3) www.avesta.tj, February 9, 18).).

(4) www.cacianalyst.org, February 2, 2011.

(4) www.ozodi.tj, March 10, 2011

(4) www.news.tj, February 9.

(5) www.news.tj, February 9, 2011.

(6) www.dw-world.de, February 28.

(9) www.regnum.ru, March 27.

(10) Nezavisimaya Gazeta, January 11,- February 11.

(11) www.cacianalyst.com, September 16, 2009. 